\title{
The connection between migration and regional structure in Finland around 1990 - a GIS viewpoint
}

JARKKO KAUPPINEN, M.Sc., Researcher

ELLI HEIKKILÄ*, Ph.D., Senior Assistant, Docent

JARMO RUSANEN, Ph.D., Senior Assistant

ARVO NAUKKARINEN, Ph.D., Professor

TOIVO MUILU, Ph.D., Senior Assistant, Docent

ALFRED COLPAERT, Ph.D., Assistant

Department of Geography, University of Oulu, Finland

${ }^{*}$ Research and Development Centre of Kajaani, University of Oulu, Finland

\section{Abstract}

The connection between migration and regional structure in Finland in the early 1990 's is discussed on the basis of Geographic Information Systems (GIS) data from Statistics Finland, compiled for map coordinate grid cells of $1 \times 1 \mathrm{~km}$. The results indicate that data of this kind enable a more detailed typology to be drawn up for migration. At the regional level, this allows the defining of places of "passing through" which gain population from other local government districts but lose population through migration within their own district. The connection between migration and regional structure is manifested in the fact that flows both between and within local government districts mainly involve the more urbanised population centres and areas with high levels of unemployment.

Keywords: Geographic Information Systems (GIS), migration, regional structure

\section{Introduction}

The development of computer-based Geographical Information Systems (GIS) commenced in the United States and Canada in the mid-1960's (it has also been proposed 
sometimes that "manual" georeferenced systems were developed still earlier (e.g. Kubo 1991:47; Ottoson \& Rystedt 1991:39), and the immense progress made in computer technology in the next twenty years or so enabled GIS to be developed rapidly for use in all kinds of spatial analysis (Aronoff 1995:32-33) employing sociological, economic and demographic material (Goodchild et al. 1993:383).

The use of grid cell material based on units of $1 \mathrm{~km}^{2}$ for the examination of migration also dates back to the 1960's. Claeson (1969), for example, relied on such data in his investigation into in-migration to urban centres in Sweden, and Vainio (1981) used data compiled for $1 \times 1 \mathrm{~km}$ squares on the Basic Map as one set of material in his doctoral thesis on migration in Finland, with a further subdivision of the squares into 16 parts of $250 \times 250 \mathrm{~m}$ each. These papers did not mention GIS or data derived from such a system, however, even though they were in fact making use of georeferenced data.

The Department of Geography at the University of Oulu has been making use of GIS data in its research programme on 'The Dynamics of the Spatial Structure of Finland' ever since 1987. The programme is concerned with exploring the possibilities for using Statistics Finland coordinate-based grid cell data to analyse regional structures, including the examination of migration at a regional level based on areal units of $1 \mathrm{~km}^{2}$ (Kauppinen et al. 1997a, 1997b, 1998a, 1998b). This paper is concerned with the connection between migration and regional structure in Finland in the early 1990's, as revealed by GIS techniques. The topic will be approached by setting out from two main themes: 1) the local classification of migration flows on the basis of the directions of net migration, and 2) classification of the migrants and the regional structure and determination of the connection between them.

\section{Material and methods}

The bulk of the material is composed of Statistics Finland grid cell migration data based on 1 x $1 \mathrm{~km}$ cells defined by map coordinates (cf. Kauppinen et al. 1997b, 1998b). This provides information on individual migrants in the years 1989, 1992 and 1994 and allows aggregation on the basis of their grid cells of departure and destination. Considered at this level, grid cell data invariably involve questions of data protection and personal privacy. The safeguard employed here is that the tables and maps etc. do not contain any data referring to just one individual, so that it is impossible to identify any actual person from the material.

The present survey defines migration in the following manner:

Migration here denotes instances of moves and permanent changes in place of residence that occur from one grid cell of $1 \mathrm{~km}^{2}$ to another, and can further be divided 
into migration occurring within and between local government districts. In addition, a new type of migration is recognised which has not been distinguished at all in earlier research, that is, local migration occurring within a single grid. Where migration usually involves a change of address and map coordinates, local migration implies only the first of these.'

In addition to migration at the individual level, this paper makes use of variables describing regional structure, again in the form of coordinate-based $1 \times 1 \mathrm{~km}$ grid cell data. Thus the coordinates enable the migration data for individuals to be combined flexibly with these regional variables. Regional structure is defined in the following manner on the basis of the material examined here:

'Regional structure is an entity composed of properties pertaining to geographical areas. It is grounded in population density, with respect to which rural and built-up areas can be recognised taking a density of 100 inhabitants $/ \mathrm{km}^{2}$ as the criterion. It also involves properties connected with distance from a centre, demographic change, migration, occupational structure and unemployment, on the basis of which regional structure can be described in terms of different categories, or regional types. '

The methods employed in the present paper are statistical analyses, a GIS system and cartographic methods. For definitions of Geographical Information Systems, see, for example, Marble (1990:10), Goodchild (1991:46-50), Huxhold (1991:25), Maguire (1991:10-11), Martin (1991:50-52), Haines-Young et al. (1993:4), Grimshaw (1994:26) and Aronoff (1995:39-43). The GIS is operated on ARC/INFO software in a UNIX environment, while most of the statistical analyses were performed using SAS statistics software. The mathematical and statistical methods employed here comprise direct distributions, cross-tabulations and multivariant grouping analyses used for the migrants and regional types.

\section{New types of migration}

One of the means of classifying migration is by characterising all the inhabited grid cells in Finland according to the direction of net migration both within and between local government districts. This provides a total of nine migration types, as shown in Table 1, which also indicates that almost two-thirds of the total inhabited area of Finland falls into the category in which no migration occurs at all. These are mostly sparsely inhabited areas, with a mean population density of seven inhabitants per square kilometre as opposed to almost 50 in the country as a whole. 
Table 1. Classification of $1 \times 1 \mathrm{~km}$ grid cells in Finland by net migration between and within local government districts in 1989, 1992 and 1994 (Data: Statistics Finland)

\begin{tabular}{|c|c|c|c|c|c|c|c|c|c|}
\hline \multirow[b]{2}{*}{$\begin{array}{c}\text { Migration } \\
\text { type }\end{array}$} & \multicolumn{3}{|c|}{$\%$ of grid cells } & \multicolumn{3}{|c|}{$\%$ of population } & \multicolumn{3}{|c|}{ Population average } \\
\hline & 1989 & 1992 & 1994 & 1989 & 1992 & 1994 & 1989 & 1992 & 1994 \\
\hline 1 & 3.0 & 3.2 & 2.8 & 15.5 & 16.7 & 16.4 & 239 & 251 & 279 \\
\hline 2 & 3.2 & 3.1 & 3.8 & 17.0 & 16.0 & 20.0 & 247 & 245 & 249 \\
\hline 3 & 3.4 & 3.4 & 3.4 & 21.1 & 22.4 & 24.0 & 286 & 315 & 338 \\
\hline 4 & 3.3 & 3.1 & 3.5 & 27.6 & 26.3 & 22.0 & 385 & 395 & 311 \\
\hline 5 & 4.7 & 5.7 & 5.1 & 1.9 & 2.4 & 2.0 & 18 & 20 & 19 \\
\hline 6 & 6.4 & 6.7 & 6.3 & 2.1 & 2.3 & 2.2 & 16 & 16 & 16 \\
\hline 7 & 5.2 & 5.2 & 5.5 & 2.0 & 1.8 & 1.8 & 18 & 17 & 16 \\
\hline 8 & 7.2 & 5.7 & 7.1 & 2.4 & 1.9 & 2.4 & 16 & 16 & 16 \\
\hline 9 & 63.6 & 64.0 & 62.5 & 10.3 & 10.1 & 9.2 & 8 & 7 & 7 \\
\hline Total & 100 & 100 & 100 & 100 & 100 & 100 & 46 & 47 & 48 \\
\hline
\end{tabular}

Migration type:

Positive internal and external migration

Positive internal and negative external migration

Positive external and negative internal migration

Negative internal and external migration

Positive internal and no external migration

Negative internal and no external migration

Positive external and no internal migration

Negative external and no internal migration

No migration

The main finding to emerge from the analysis is that in 1994 the most densely populated areas gained from migration between local government districts but lost some of their population through internal migration. These areas had a mean population density of 338 inhabitants per square kilometre and accounted for one fourth of the country's total population and ranged in geographical distribution from the Kallio district of southwest Helsinki to the Tuira district in the northern part of the city of Oulu (Fig. 1). In terms of migration, these can be looked on as cases of "passing through", in that people move there from other localities, live there for some time and then move on.

The overlay technique for applying GIS analyses to geographical research (cf. Martin 1991:52; Tomlin 1991:368-369) allows the places of passing through, i.e. areas with negative net internal migration but positive external migration, to be picked out simultaneously for each of the years 1989, 1992 and 1994. The results indicate that the migration type seldom remains unchanged in quantitative terms, although locally its permanence may be a very important feature (cf. Kauppinen et al. 1998a, 1998b). In Helsinki in particular these passing through places have remained the same to a large extent. 
Figure 1. Migration in the environments of Helsinki and Oulu in 1994 (Data: Statistics Finland; Map: University of Oulu, Department of Geography, 1998).

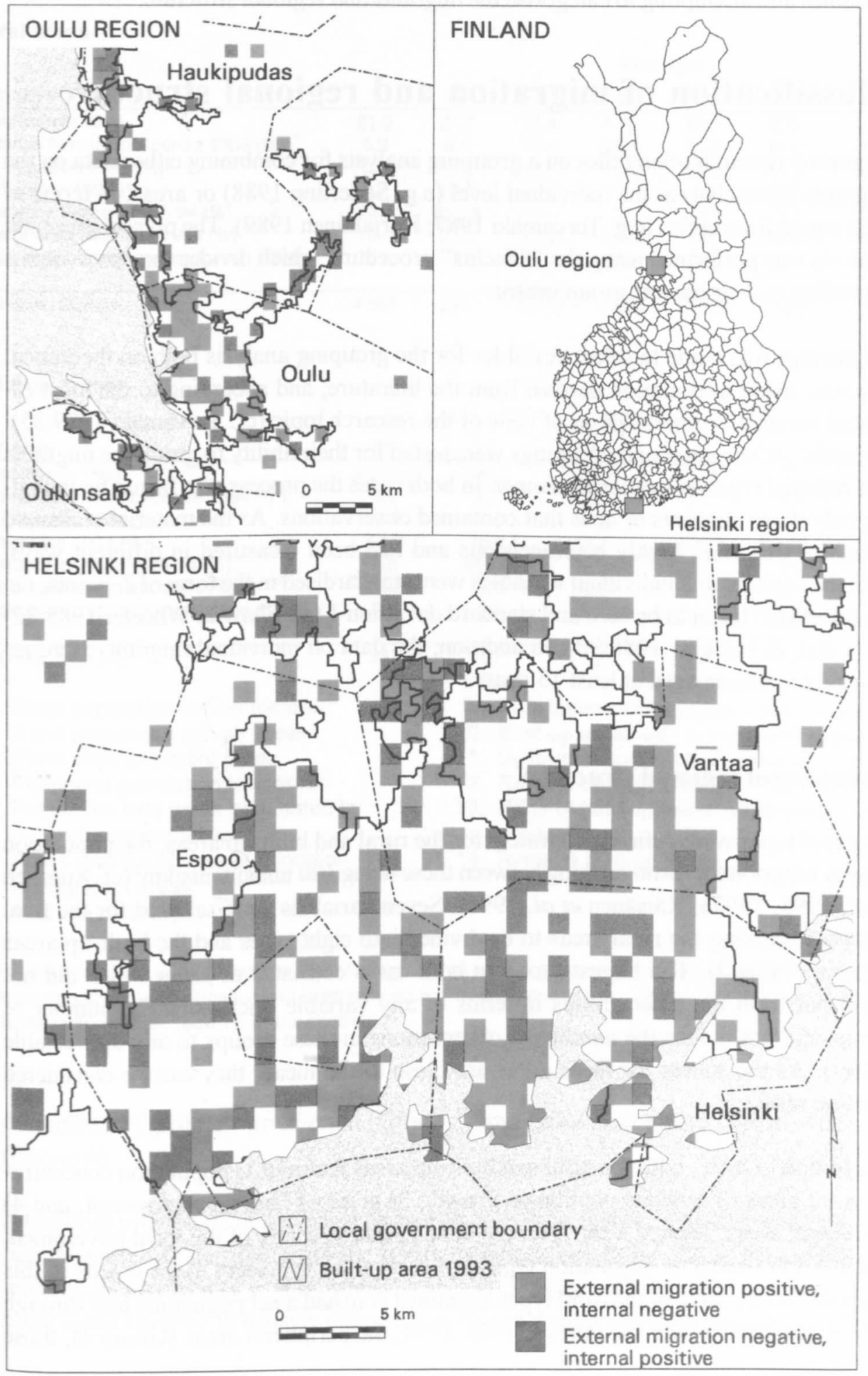


Where the above classification of migration in local terms considered only the direction of net migration, we will now extend the analysis by including a number of other variables and attempting to categorise the migrants and regional structure.

\section{Classification of migration and regional structure}

Migration research often relies on a grouping analysis for combining either data on the migrants themselves at the individual level (e.g. Söderling 1988) or areas, in terms of their regional variables (e.g. Tervamäki 1987; Karjalainen 1989). The present grouping analysis was performed using the "fastclus" procedure, which divides the observations according to their nearest group centre.

An attempt was made to select variables for the grouping analysis both on theoretical grounds, using information derived from the literature, and according to the most essential variables from the point of view of the research topic (cf. Tervamäki 1979:35). A number of variables and groupings were tested for their ability to group the migrants and regional types in a rational manner. In both cases the process was begun by including only those migrants or cells that contained observations. As the material contained variables that were highly heterogeneous and had been measured in different ways, both the regional and individual variables were standardised in the form of Z-points, i.e. the mean was taken to be zero and standard deviation 1 (cf. Shaw \& Wheeler 1985:8283; Clark \& Hoskins 1986:90). In addition, the data on individual migrants were restricted to persons aged at least 15 years.

\section{Grouping of regional structure}

Regional types were defined separately for the rural and built-up areas, the population density criterion for distinguishing between these being 100 inhabitants $/ \mathrm{km}^{2}$ (cf. Rusanen et al. 1995, 1997a; Räisänen et al. 1996). Seven variables were selected for the final analyses enabling the rural areas to be divided into eight types and the built-up areas into six (Table 2). The largest group in both cases consisted of areas which did not stand out from the other groups in terms of any variable (increasing the number of groups did not reduce the number of observations in these groups to any appreciable extent). As the scores for these areas are close to the mean, they can be considered average areas.

In addition to these, both the rural and built-up areas featured 1) population concentrations, 2) areas of obvious population growth, 3) areas of high unemployment, and 4) peripheral areas, located a far from the administrative centre of the local government district. The decline in population typical of rural areas is evident in the results of this analysis, in that three of the rural types examined here had a net population loss through external migration over the interval 1985-1994; the peripheral areas (Group 4), those 
Table 2. Grouping of rural and built-up areas and means for the variables used in the analyses in 1994 (Data: Statistics F inland)

\begin{tabular}{|c|c|c|c|c|c|c|c|c|}
\hline \multicolumn{9}{|l|}{ Rural areas } \\
\hline \multirow[b]{2}{*}{ Variable } & \multicolumn{8}{|c|}{ Groups } \\
\hline & 1 & 2 & 3 & 4 & 5 & 6 & 7 & 8 \\
\hline Population in 1994 & 61.5 & 22.7 & 15.4 & 17.0 & 12.1 & 6.8 & 7.8 & 19.4 \\
\hline Distance from district centre $1994(\mathrm{~km})^{1}$ & $\frac{91.0}{6.9}$ & 9.4 & 10.4 & $\underline{36.4}$ & 11.3 & 11.0 & 11.3 & 8.2 \\
\hline Out-migration 1994 (\%) & 5.9 & 9.3 & 9.6 & 11.5 & 13.0 & $\underline{55.3}$ & 3.1 & 8.6 \\
\hline In-migration $1994(\%)$ & 5.7 & 18.1 & 8.4 & 7.5 & 4.4 & 40.8 & 49.9 & 6.2 \\
\hline Population change 1985-94 (\%) & 12.3 & 431.3 & 1.1 & -7.1 & -14.1 & -3.8 & 39.3 & 9.0 \\
\hline Rate of unemployment $1994(\%)$ & 19.4 & 22.2 & 45.2 & 29.5 & 9.7 & 14.8 & 16.0 & 11.1 \\
\hline $\begin{array}{l}\text { Employment in primary production } 1994 \\
(\%)\end{array}$ & 15.6 & 13.1 & 25.7 & 40.1 & $\underline{75.4}$ & 31.0 & 23.1 & 15.9 \\
\hline Grid cells, total (N) & 4861 & 591 & 5072 & 1413 & 6258 & 1120 & 1476 & 9455 \\
\hline
\end{tabular}

\section{Built-up areas}

\begin{tabular}{lcccccc} 
Variable & $\mathbf{9}$ & $\mathbf{1 0}$ & $\mathbf{1 1}$ & $\mathbf{1 2}$ & $\mathbf{1 3}$ & $\mathbf{1 4}$ \\
\hline Population in 1994 & $\underline{373.3}$ & $\mathbf{5 9 0 . 3}$ & 733.3 & 405.7 & 147.9 & 455.0 \\
Distance from district centre 1994 (km) & 4.6 & 4.8 & 2.6 & $\underline{13.3}$ & 5.8 & 2.7 \\
Out-migration 1994(\%) & 13.0 & 11.2 & 14.4 & 8.2 & 4.9 & 7.5 \\
In-migration 1994 (\%) & 13.0 & 16.0 & 14.7 & 7.8 & 4.8 & 7.0 \\
Population change 1985-94 (\%) & 3.6 & $\underline{515.9}$ & 17.3 & 24.6 & 6.9 & 19.5 \\
Rate of unemployment 1994(\%) & 20.2 & 19.6 & $\underline{26.0}$ & 19.0 & 18.0 & 17.4 \\
Employment in primary production 1994 & 0.5 & 1.9 & 3.3 & 2.9 & $\underline{24.4}$ & 3.3 \\
(\%) & & & & & & \\
\hline Grid cells, total (N) & 331 & 151 & 1326 & 617 & 260 & 2768
\end{tabular}

1. Rural population concentrations

2. Rural population growth areas

3. Rural unemployment areas

4. Peripheral population loss areas

5. Population loss areas dominated by primary production

6. Areas with a high rate of migration

7. In-migration areas

8. Average rural areas
9. Population concentrations of built-up areas

10. Built-up areas with pronounced population growth

11. Built-up areas with high unemployment

12. Remote built-up areas

13. Parts of built-up areas dominated by primary production

14. Average built-up areas

${ }^{1}$ A district centre is defined here as the $1 \times 1 \mathrm{~km}$ cell in a local government district that has the largest number of persons employed in the finance and insurance sector. Earlier research has shown that this provides a fairly accurate picture of the location of the centre.

dominated by primary production (Group 5) and those with a high rate of migration (Group 6).

It has been previously observed on numerous occasions that the mobility of the population decreases as distance from the centre increases, due to the fall in the numbers of inhabitants involved (e.g. Hägerstrand 1957:34-35; Cadwallader 1982:459-461). Mobility is thus highest in densely populated urban areas and lowest in sparsely populated 
peripheral areas. The results obtained here do not support this hypothesis, however, as in-migration and out-migration per capita were evidently highest in the most sparsely populated rural areas, where the average population density was only seven inhabitants per square kilometre and the distance from the district centre was greater than average. These can be regarded as high migration areas (Group 6). There was a statistically significant positive correlation (Spearman's correlation coefficient) between mobility and distance in all the years examined here (e.g. 0.1267 in 1994), i.e. mobility increased with distance from the administrative centre of the district. Another group which stands out clearly in terms of its migration variables concerns rural areas with in-migration well in excess of out-migration (Group 7).

The size of grid cell used here $(1 \times 1 \mathrm{~km})$ must influence the results, as the settlement structure of Finland involves a large number of cells with an extremely low population density (Rusanen et al. 1995, 1997a). Thus per capita migration figures easily become high even if only a small number of people actually move.

\section{Grouping of migrants}

As the GIS material at the individual level allowed an entirely new type of migration to be distinguished, local migration taking place within the same grid cell, a grouping analysis was performed with migration type as the main criterion. The grouping procedure was applied separately for persons who had moved 1) within a local government district, 2) from one district to another and 3) within a grid cell. A total of 12 variables were selected for the analysis, which yielded 19 categories of migrants (cf. Korkiasaari 1991): nine for persons who had moved within a local government district (total 214,580 migrants), six for migration between districts (135,587 migrants) and four for migration within a grid cell (59,557 migrants). Most of the variables analysed here were classified ones, i.e. they represented qualitative differences arranged on a nominal scale, the exceptions being age, family size and migration distance, which represented a ratio scale. As variables of the former kind are problematic when using multivariant methods, they were converted here into dummy variables (cf. Clark \& Hoskins 1986:425433 ), with only two categories assigned to them: $0=$ the finding has no describable dimension, and $\mathrm{l}=\mathrm{a}$ describable dimension exists.

Unlike the classification of regional structure, only a few groups of migrants could be distinguished on the grounds of one single variable. Thus most of the groups were named on the basis of more than one variable. As migration within and between local government districts largely featured similar migrant groups, means for the variables are presented here only for persons who had moved within a local government district (Table 3). Certain significant observations regarding groups that emerged within the various migration types are presented next. 
Table 3. Grouping of migrants within a local government district and means for the variables used in the analysis, 1994 (Data: Statistics Finland)

\begin{tabular}{|c|c|c|c|c|c|c|c|c|c|}
\hline \multirow[b]{2}{*}{ Variable } & \multicolumn{9}{|c|}{ Groups } \\
\hline & 1 & 2 & 3 & 4 & 5 & 6 & 7 & 8 & 9 \\
\hline Age & $\underline{26.0}$ & 67.1 & 30.2 & 37.3 & 37.2 & 35.4 & $\underline{27.6}$ & 32.0 & 28.6 \\
\hline Main occupation before moving & 0.3 & 0.0 & 0.3 & 0.3 & 0.9 & 0.9 & $\overline{0.1}$ & $\underline{0.9}$ & $\underline{0.1}$ \\
\hline Main occupation after moving & 0.4 & 0.0 & 0.4 & 0.3 & 0.9 & 1.0 & 0.2 & $\underline{0.9}$ & $\underline{0.1}$ \\
\hline Home occupancy before moving & 1.0 & 0.7 & 0.4 & 0.7 & $\underline{0.8}$ & 0.7 & $\underline{0.5}$ & $\underline{0.2}$ & $\underline{0.2}$ \\
\hline Home occupancy after moving & 0.1 & 0.4 & 0.2 & 0.4 & $\underline{0.9}$ & 0.8 & $\underline{0.8}$ & $\underline{0.1}$ & $\underline{0.2}$ \\
\hline Type of house before moving & 0.9 & 0.5 & 0.4 & 0.8 & $\underline{0.5}$ & 0.6 & $\underline{0.5}$ & $\underline{0.1}$ & $\underline{0.1}$ \\
\hline Type of house after moving & 0.2 & 0.3 & 0.4 & 0.6 & 0.7 & 0.9 & 1.0 & 0.1 & 0.1 \\
\hline Living space before moving & 0.7 & 0.9 & 0.1 & 0.6 & 0.9 & $\underline{0.2}$ & 0.6 & 0.9 & 0.6 \\
\hline Living space after moving & 0.8 & 0.8 & 0.0 & 0.6 & 0.9 & $\underline{0.6}$ & 0.8 & 0.8 & 0.8 \\
\hline Family size before moving & 3.5 & 1.5 & 4.1 & 2.8 & 2.1 & $\underline{3.9}$ & 2.8 & 1.8 & 1.9 \\
\hline Family size after moving & 1.7 & 1.4 & $\underline{4.1}$ & 2.2 & 2.1 & $\underline{3.9}$ & 2.9 & 1.8 & 1.7 \\
\hline Distance moved & 4.1 & 4.1 & $\overline{3.8}$ & 23.0 & 3.8 & $\overline{3.5}$ & 3.8 & 3.8 & 3.8 \\
\hline Number or persons moving $(\mathrm{N})$ & 26276 & 22100 & 20506 & 5201 & 28070 & 20732 & 17186 & 39847 & 34662 \\
\hline \multicolumn{10}{|l|}{$\begin{array}{l}\text { Dummy variables: } \\
\text { - Main occupation } \\
\text { - Home occupancy } \\
\text { - House type } \\
\text { - Living space }\end{array}$} \\
\hline \multicolumn{10}{|c|}{$\begin{array}{l}\text { Migrant groups: } \\
\text { 1. Persons leaving home } \\
\text { 2. Retired people } \\
\text { 3. Migrants with families } \\
\text { 4. Long-distance migrants } \\
\text { 5. Single migrants seeking better accommodation } \\
6 \text {. Migrants with families seeking better accommodation } \\
\text { 7. Young persons buying a home of their own } \\
\text { 8. Employed persons moving from one rented apartment to another } \\
\text { 9. Marginalised persons }\end{array}$} \\
\hline
\end{tabular}

According to earlier research, factors connected with housing conditions are among the main ones that give rise to migration within a district. This was also evident here. The following internal migration groups could be distinguished on the basis of the housing factors: 1) persons living alone and moving from one owner-occupied dwelling to another within the same residential area (Group 5), 2) families moving to a larger house (Group 6), and 3) young people buying their first home (Group 7). A further category recognised in the case of migration between local government districts was people moving on account of their work.

A special group of internal migrants comprised single persons not at work who were moving from one rented apartment to another (Group 9). This represents an average group in a certain sense, but was termed here the marginalised group on account of the other attributes of the migrants. As the average age of this group was fairly low, we can assume that it also includes students. 
One interesting and rather exceptional group was migrant group 7. These young persons bought a home of their own though they were not employed before or after their migration. Within this research it is impossible to make far-reaching conclusions about factors that would explain this phenomenon. It is possible, for example, that there are certain cultural and social structures that enable such a move.

Entirely new groups of migrants recognised here were the local migrants, i.e. persons moving within the same grid cell. There were four such groups: 1) families moving from one rented apartment to another, 2) single persons moving from one owneroccupied apartment to another, 3) families moving from one private house to another in the same area, and 4) single persons moving form one private house to another in the same area. The groups also differed in terms of the fact that the people with families were younger on average and were generally moving to a more spacious accommodation, although the amount of space per person, even after moving, was still markedly less than for the migrants with no families.

The most important connecting point between these new groups of migrants identified here was that they moved within the grid cell. These local migrants covered almost 15 $\%$ of all migrants. Maybe this result reveals something about attachment to current surroundings.

\section{Connections between migration and regional structure}

The migration data at the individual level can be combined with the data on regional structure via the map coordinates. This allows an examination to be made of the type of regional structure from which migration sets out at the local level and what its direction is. The present analytical approach enables this to be examined in more detail than is possible when relying on a classification in terms of population density alone (cf. Kauppinen et al. 1997a, 1997b). One assumption underlying the economic push-pull hypothesis is that migration always takes place from areas with a high rate of unemployment to areas with a lower rate (Shaw 1975:72; cf. also DaVanzo 1978:507-512; Tervo 1997:14-17).

The results regarding migration flows between regional types indicate that the numbers of migrants were largest in absolute terms in the case of migration between population concentrations in built-up areas (Fig. 2). In addition, in the case of eleven departure areas out of 14, the main migration flow was towards a built-up area with a high rate of unemployment. Thus the basic assumption in the push-pull hypothesis, that a high rate of unemployment reduces in-migration, would seem not to hold, at least not in the present analysis. Results at variance with the hypothesis have been presented by Nelson (1959), Lowry (1966), Rogers (1967), Greenwood (1969:192-193) and Pissarides \& Wadsworth (1989), for example. It should be borne in mind, however, that surveys 
differ in the way in which they define a region, so that Tervo (1997), for example, used the 12 provinces of Finland. It could be interesting to include other variables to the analysis to elaborate the qualities of destination areas as well as sending areas. This could yield new information about the economic push-pull hypothesis.

Figure 2. Directions of the main migration flows by area of departure in 1994 . The size of each flow is indicated by the thickness of the arrow (Data: Statistics Finland)

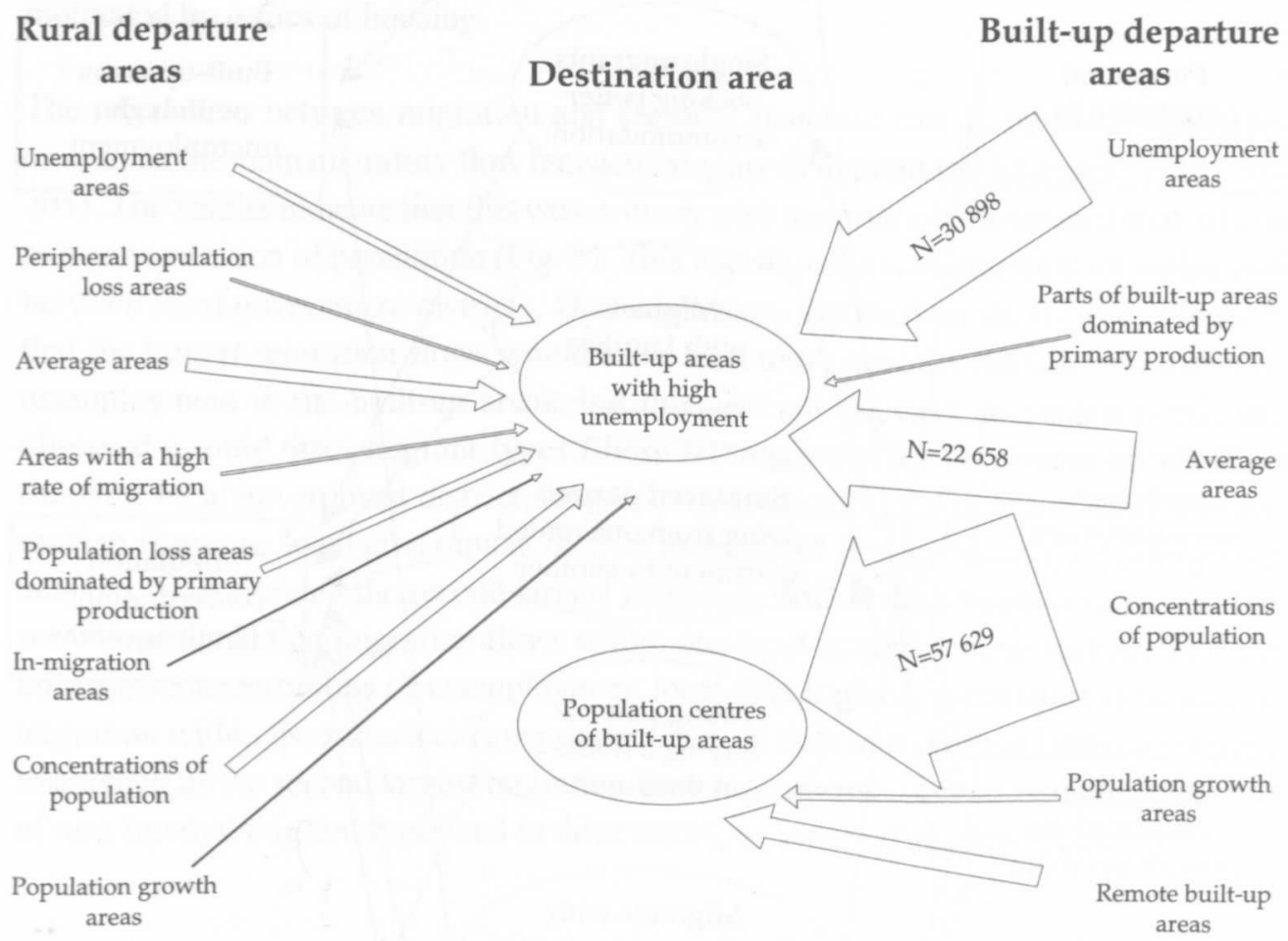

The analysis was consequently pursued further by examining the directions of migration flows with regard to the rate of unemployment prevailing in the areas of departure and destination. The results indicated that the direction was usually towards areas with an average rate of unemployment regardless of the relation between the area of departure and the destination. Thus there was no obvious correlation between the unemployment rates in the two areas as one might assume from Figure 2. 
Figure 3. Main internal migration flows in 1994 by migrant category (Data: Statistics Finland).

\section{Departure area}

Migrant category

Destination area

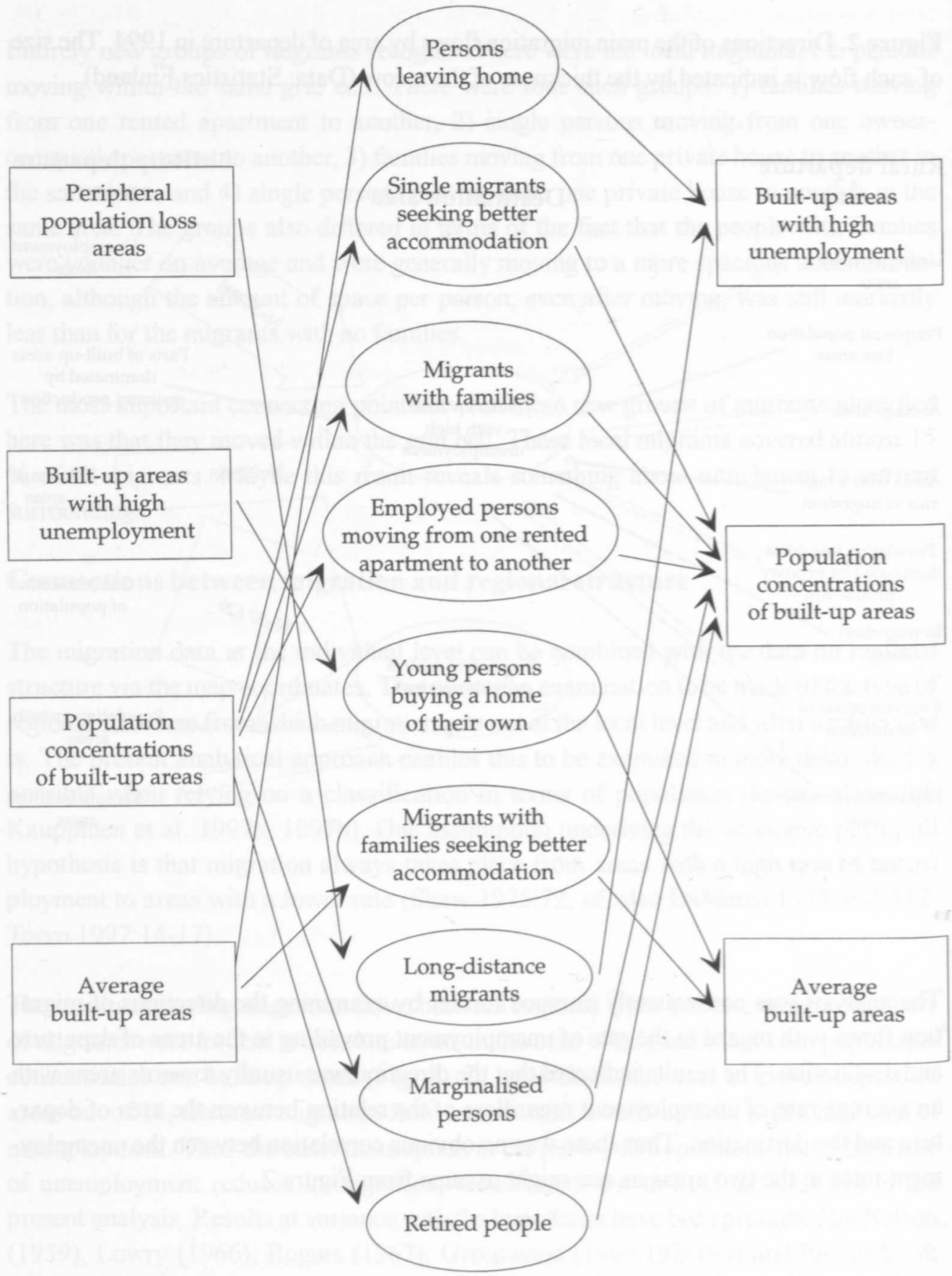


Migration gains were recorded for only five out of the 14 regional types: 1) unemployment areas, 2) population growth areas and 3) concentrations of population among the built-up areas, 4) population growth areas and 5) in-migration areas in the rural category. The greatest migration losses in absolute terms were recorded for the areas of population loss dominated by primary production. Young people wanting to move away were the largest group of out-migrants in the rural areas, typically departing for the population concentrations in the built-up areas and the areas characterised by high unemployment in the case of movement both within and between local government districts. These areas in turn lost population on account of various kinds of migration motivated by issues of housing.

The interaction between migration and regional structure can be outlined simply by examining the main migratory flow for each category of migrant (cf. Söderling 1988:203205). The results indicate that this was in every case towards a built-up area that served as a concentration of population (Fig. 3). This was the case in migration both within and between local government districts. One might have assumed on the basis of Figure 2 that the largest migration flows would have been more towards the concentrations of unemployment in the built-up areas, but this was not the case, as such a trend was observed in only three migrant types (those leaving home for accommodation within the same local government district, long-distance migrants, and migrants with families moving from one local government district to another). It was decided to continue the analysis by examining the second largest migration flow in each migrant category. The results indicated that migration flows within one local government district are focused on major concentrations of unemployment located in built-up areas more distinctly in migration within the same local government district than in migration from one district to another, as the second largest migration flow was towards such areas among five out of nine internal migrant types and in three out of six external migrant types.

\section{Conclusions}

We are concerned here with the connection between migration and regional structure at the individual level in Finland, the observations being aggregated for areal units of 1 $\mathrm{km}^{2}$. Cases of passing through in migration were identified on the basis of the detailed grid cell data and their location was determined more accurately than in previous research. The results also indicated that these areas have remained almost unchanged locally, particularly in Helsinki, the capital of Finland. They have thus become steppingstones for people moving to the district from elsewhere, who live in rented accommodations for as long as it is necessary to find somewhere that will suit their family needs better, for example. It is impossible to state on the basis of the present data whether the reasons for this lie in the housing available in different areas, their relative pleasantness 
or image, or some other factor. In any case it is possible for local authorities to recognise this situation and intervene in it to bring about changes where necessary.

The main finding to emerge from this research into the connection between migration and regional structure was that migration flows both between and within local government districts are concentrated in just a few specific areas. Although slightly over onethird of all the instances of migration were directed towards population concentrations in built-up areas, these areas accounted for no more than $0.9 \%$ of the grid cells analysed. Some of the present findings go against standard migration theories, e.g. in that per capita in-migration and out-migration were most extensive in the most sparsely populated areas and not in the densely populated urban areas. The crucial factor in this discrepancy may well be the nature of the data and areal unit used in this investigation.

The use of accurate GIS material involves both advantages and disadvantages. The former, as perceived here, include 1) the ability to classify migration at a more detailed level than the local government district, 2) the ability to use the same data to examine migration between districts, within a district and locally (within a grid cell), 3) the fact that the grid cells are independent of administrative boundaries, although they can be aggregated at the local government level when necessary, and 4) the grid cells are permanent in their location. The following issues may be regarded as problematic from a research point of view: 1) the grid cell is an abstract unit which cannot be easily appreciated as an integral area, 2) the material is extensive and therefore laborious and time-consuming to process, 3 ) the variables have a skewed distribution, which prevents the use of indices or analyses based on the assumption of normality, 4) the settlement structure of Finland is characterised by a substantial number of extremely sparsely populated grid cells, making it difficult to analyse, particularly with regard to proportional variables, and 5) migration affects only a third of the inhabited grid cells in Finland. The fact that a considerable amount of sparsely populated territory lies outside the scope of the analysis means that the picture given by the present survey as far as the rural areas are concerned does not necessarily correspond well to the situation in the country as a whole.

\section{Acknowledgements}

The work was financed by the Foundation for Municipal Development, the Finnish Ministry of Agriculture and Forestry, the Kyösti Haataja Foundation of the Cooperative Banking Group and the Emil Aaltonen Foundation. The paper was translated into English by Malcolm Hicks. The authors wish to thank all the above instances who have contributed to the completion of the work and to their participation in the $45^{\text {th }}$ Annual North American Meeting of the Regional Science Association International in Santa Fe, New Mexico, USA. 


\section{References}

Aronoff, Stan. 1995. Geographic Information Systems: A management perspective. 5. printing. Ottawa: WDL Publications.

Cadwallader, Martin. 1982. Urban residential mobility: a simultaneous equation approach. Transactions, New Series, Institute of British Geographers 7(4): 458-473.

Claeson, Claes-Fredrik. 1969. A two-stage model of in-migration to urban centres: deductive development of a variant of the gravity formulation. Geografiska Annaler 52 B(2): $127-$ 138.

Clark, W. A. V. \& P. L. Hoskins. 1986. Statistical methods for geographers. New York: John Wiley \& Sons.

DaVanzo, Julie. 1978. Does unemployment affect migration? - Evidence from microdata. The Review of Economics and Statistics 60: 504-514.

Goodchild, M. F. 1991. The technological setting of GIS. In: Geographical Information Systems, Principles, edited by Maguire, David. J., Michael F. Goodchild \& David W. Rhind, pp. 45-54. New York: Longman.

Goodchild, M. F., L. Anselin \& U. Deichmann. 1993. A framework for the areal interpolation of socioeconomic data. Environment and Planning A 25: 383-397.

Greenwood, Michael J. 1969. An analysis of the determinants of geographic labor mobility in the United States. The Review of Economics and Statistics 51(2): 189-194.

Grimshaw, David J. 1994. Bringing Geographical Information Systems into business. New York: Longman.

Haines-Young, R., D. R. Green \& S. Cousind. 1993. Landscape ecology and geographical information systems. In: Landscape ecology and GIS, edited by Haines-Young, Roy, David R. Green \& Stephen H. Cousins, pp. 3-8. London: Taylor \& Francis.

Huxhold, William E. 1991. An introduction to urban Geographic Information Systems. New York: Oxford University Press.

Hägerstrand, Torsten. 1957. Migration and area. In: Lund Studies in Geography B 13, Migration in Sweden. A symposium, edited by Hannerberg, David, Torsten Hägerstrand \& Bruno Odeving, pp. 27-158.

Karjalainen, Elli. 1989. Migration and regional development in the rural communes of Kainuu, Finland in 1980-85. Nordia 23(1): 89 p.

Kauppinen, Jarkko, Elli Heikkilä, Jarmo Rusanen, Toivo Muilu, Arvo Naukkarinen \& Alfred Colpaert. 1998a. Kallio, Pateniemi ja Tuira - läpikulkupaikkoja? Kuntapuntari 2: 8-12.

Kauppinen, Jarkko, Elli Heikkilä, Jarmo Rusanen, Arvo Naukkarinen, Toivo Muilu \& Alfred Colpaert. 1998b. GIS in the study of migration in Finland at different regional levels. Nordia Geographical Publications 27(1):1-13. Oulu.

Kauppinen, Jarkko, Elli Rissanen, Jarmo Rusanen, Toivo Muilu, Arvo Naukkarinen \& Alfred Colpaert. 1997a. Asutus tiivistyy kaupunkien sisälläkin. Tietoaika 11: 8-11.

Kauppinen, Jarkko, Elli Rissanen, Jarmo Rusanen, Arvo Naukkarinen, Toivo Muilu \& Alfred Colpaert. 1997b. Migration as a function of population. Nordia Geographical Publications 26(1): 17-27.

Korkiasaari, Jouni. 1991. Liikkuvuus ja rakennemuutos. Maassamuutto ja työvoiman liikkuvuus osana yhteiskunnan rakennemuutosta. Työministeriö, Työpoliittinen tutkimus 11. 185 p.

Kubo, S. 1991. The development of GIS in Japan. In: Geographical Information Systems, Applications, edited by Maguire, David J., Michael F. Goodchild \& David W. Rhind, pp. 47-56. New York: Longman Scientific \& Technical. 
Lowry, Ira S. 1966. Migration and metropolitan growth: two analytical models. San Francisco: Chandler Publishing Company.

Maguire, D. J. 1991. An overview and definition of GIS. In: Geographical Information Systems: Principles, edited by Maguire, D. J., Michael F. Goodchild \& David W. Rhind, pp. 9-20. New York: Longman.

Marble, Duane F. 1990. Geographic Information Systems: an overview. In: Introductory readings in Geographic Information Systems, edited by Peuquet, Donna J. \& Duane F. Marble, pp. 8-17. New York: Taylor \& Francis.

Martin, David. 1991. Geographic Information Systems and their socioeconomic applications. London and New York: Routledge.

Nelson, Philip. 1959. Migration, real income and information. Journal of Regional Science 1(2): 43-74.

Ottoson, L. \& B. Rystedt. 1991. National GIS programmes in Sweden. In: Geographical Information Systems, Applications, edited by Maguire, David J., Michael F. Goodchild \& David W. Rhind, pp. 39-46. New York: Longman Scientific \& Technical.

Pissarides, Christopher A. \& Jonathan Wadsworth. 1989. Unemployment and the inter-regional mobility of labour. The Economic Journal 99: 739-755.

Rogers, Andrei. 1967. A regression analysis of interregional migration in California. The Review of Economics and Statistics XLIX(2): 262-267.

Rusanen, Jarmo, Alfred Colpaert, Arvo Naukkarinen \& Satu Räisänen. 1995. Grid-based statistical data for regional research - Finnish experiences. Nordia Geographical Publications 24(2): 91-102.

Rusanen, Jarmo, Arvo Naukkarinen, Alfred Colpaert \& Toivo Muilu. 1997a. Differences in the spatial structure of the population between Finland and Sweden in 1995 - a GIS viewpoint. Statistics Finland, Research Reports 221. 46 p.

Räisänen, Satu, Jarmo Rusanen \& Arvo Naukkarinen. 1996. Socio-economic grid data and GIS for analyzing changes in the Finnish countryside. In: Geographical Information. From research to application through cooperation 1 , edited by Rumor, M., R. McMillan \& H. F. L. Ottens, pp. 651-660. Amsterdam: IOS Press.

Shaw, R. Paul. 1975. Migration theory and fact. Philadelphia: Regional Science Research Institute.

Shaw, Gareth \& Dennis Wheeler. 1985. Statistical techniques in geographical analysis. Chichester: John Wiley \& Sons.

Söderling, Ismo. 1988. Maassamuuton ulottuvuudet. Annales Universitatis Turkuensis C 65. $279 \mathrm{p}$.

Tervamäki, Erkki. 1979. Maantieteen tilastollista metodiikkaa. Helsingin yliopiston maantieteen laitoksen opetusmonisteita 10. 3. printing.

Tervamäki, Erkki. 1987. Migration in Finland, a multi-level system of regions. Fennia 165(1): $88 \mathrm{p}$.

Tervo, Hannu. 1997. Long-distance migration and labour market adjustment: empirical evidence from Finland 1970-90. University of Jyväskylä, School of Business and Economics, Working Paper 168. $20 \mathrm{p}$.

Tomlin, C. D. 1991. Cartographic modelling. In: Geographical Information Systems: Principles, edited by Maguire, D. J., Michael F. Goodchild \& David W. Rhind, pp. 361374. London: Longman.

Vainio, Juhani. 1981. Flyttningrörelse och avfolkning i sydvästra Finlands skärgård. Annales Universitatis Turkuensis A 65. 158 p. 